\title{
Akože, nejaký: reč na súde mimo zápisnice. Prípadová štúdia súdneho pojednávania so žiadatel'om o azyl
}

\author{
Helena Tužinská \\ DOI: 10.21104/CL.2018.4.04 \\ As if to say, kind of: courtroom talk not in the record. \\ A case study of court proceedings with an asylum applicant
}

\begin{abstract}
In this study, I examine the linguistic means that weaken the effect of an asylum applicant's speech during court proceedings: the overuse of selected words implying doubt, uncertainty, assumption, or presumption signal imbalance. I analyse how the hegemonic practices of consensus are reflected in the tolerance of the interpreter's inconspicuous mistakes: the use of the third person instead of the first, the use of passive instead of active voice, the concealment of the subject or the author, and the subordination of the subjectivity of the asylum applicant's testimony in both linguistic and non-linguistic forms. This case study presents the partial results of the ethnographic research that took place at hearings of asylum applicants between 2015 and 2018 at the Regional Court in Bratislava. I focus on the linguistic practices which significantly influenced the atmosphere of a hearing; the applicant was not aware of the expressions which were adjoined to his speech and weakened his argumentation. These expressions were also not part of the official record. I interpret the linguistic means of identity
\end{abstract}

construction in courts in accordance with the anthropological and sociolinguistic works of Diana Eades, Anthony Good, Katrijn Maryns, and Susan Philips. In a broader context, I also make use of Pierre Bourdieu's theory of production and reproduction of legitimate language.

Key words language, court, asylum applicants.

Táto práca bola podporovaná Vedeckou grantovou agentúrou MŠVVaŠ SR a SAV (VEGA) a bola súčast́ou riešenia projektu č. 1/0421/17.

Contact Mgr. Helena Tužinská, PhD., Katedra etnológie a muzeológie, Filozofická fakulta Univerzity Komenského, Gondova 2, Bratislava 814 99, Slovak Republic; e-mail: helena.tuzinska@uniba.sk.

Jak citovat / How to cite Tužinská, Helena. (2018). Akože, nejaký: reč na súde mimo zápisnice. Prípadová štúdia súdneho pojednávania so žiadatel'om o azyl. Český lid 105, 441-458. doi: http://dx.doi.org/10.21104/CL.2018.4.04 


\section{Úvod}

Etnografia komunikácie je interdisciplinárnou oblast’ou na pomedzí antropológie a lingvistiky. Výskum tohto typu sa sústreduje na použitie jazyka ako súčasti sociálnych vztahov a identít vo verbálnej aj neverbálnej rovine. Pozorovanie problémov, ktoré vznikajú v interkultúrnej komunikácii, reflektovali predovšetkým zásadné práce Johna Gumperza, vymedzujúce rozdiel medzi významom vety a zámerom hovoriaceho. Za posledné necelé polstoročie vzniklo mnoho podnetných prác, ktoré dešifrujú zdiel'ané sociokultúrne poznanie účastníkov komunikácie a kontextualizačné klúče, ktoré im napovedajú o zámere komunikátu. Jeden zo známych prístupov v diskurznej analýze, tzv. „difference approach“ bol kritizovaný za to, že ignoruje sociálnu nerovnost' a mocenské vztahy v medzikultúrnych stretoch, ako aj ich politickú dimenziu (Eades 2008: 32-35) V posledných rokoch sa pole výskumu diskurznej analýzy rozširuje o interdisciplinárny výskum, čím diskurzná analýza vystupuje zo svojej mainstreamovej „značne textuálnej a lingvistickej orientácie“ (Blommaert 2011: 127).

Zásadný obrat v tomto smere znamenali práce Johna Conleyho a Williama O’Barra. Tí kritizovali sociolingvistiku za jej obmedzenie na situované interakčné otázky, predovšetkým tvárou v tvár. Conley a O’Barr (2005) komunikáciu v súdnej sieni analyzujú ako súčast' vplyvov, ktoré toto prostredie prestupujú - historických, ideologických či rodových. Hladajú odpovede na sociolingvistické a socioprávne teoretické otázky, využívajúc etnografiu komunikácie a teóriu právnej antropológie.

Ďalšou autorkou, ktorá významnou mierou prispela k interdisciplinárnej spolupráci antropológie a sociolingvistiky, je Diana Eadesová (2008). Na príklade analýzy sporu Pinkeba - súdneho pojednávania s troma aborigénnymi chlapcami - mimoriadne detailne ukazuje, aký mocenský presah majú lingvistické stratégie právnikov v krížovom výsluchu. Ukazuje, aké typy otázok evokujú isté typy odpovedí, aj aké sociálne príčiny a dôsledky majú tieto interakcie. Diana Eadesová analyzuje toto súdne pojednávanie simultánne na troch úrovniach: 1) situačný spor, 2) inštitucionálny spor aj ako 3) spoločenský zápas.

Slová sú pritom podl'a Gramsciho terminológie súčastou hegemonických praktík nastolovania súhlasu. Zaujíma ju predovšetkým, akými spôsobmi je v súdnej sieni reprodukovaný sociálny poriadok ako „samozrejmý“, napríklad aj prostredníctvom zvolenia poradia a foriem otázok, či vol'by výrazových prostriedkov vrátane ticha. Jej kniha je tak odpoved'ou na výzvu Johna Conleyho a Williama O’Barra, aby vznikali také štúdie o jazyku a práve, ktoré identifikujú lingvistické mechanizmy uskutočňovania aj zneužitia moci. Svoj etnografický výskum prepája s kritickou sociolingvistikou, pričom skúma špecifickú rolu jazyka v sociálnej konštrukcii nerovných vztáahov. V prípade Pinkeba Eadesová analyzuje celú škálu lingvistických mechanizmov, 
ktoré konštruujú aboriginalitu v termínoch kriminality a ohrozenia verejného poriadku, a tak prispievajú k legitimizácii policajnej kontroly a neokoloniálnych praktík v Austrálii.

Lingvistické mechanizmy konštrukcie identity sú rozmanité. Okrem rôznorodých prozodických čŕt je možné použit akýkolvek slovný druh na zvýšenie alebo oslabenie argumentačnej sily prejavov. Z tejto širokej plejády možností upozorňujem na sekvencie, v ktorých „akože“ a „nejaké“ uberajú na sile opisu situácie žiadatel'om o azyl. Tlmočník pridávaním týchto slov k výpovedi žiadatel'a o azyl nielen vyjadril svoj vzt́ah k vecnému obsahu výpovede, ale aj determinoval celý svoj prejav (vid' Mistrík, 1985: 84). Podla Šimkovej (2001), častice stoja za spôsobom pomenovania postojov hovoriaceho ku skutočnosti, k adresátovi alebo k iným účastníkom komunikácie, k obsahu a forme výpovede, obsahujú príznaky ako subjektívnost', objektívnost', klad, zápor, istota, neistota, informácia, želanie, výzva, hodnotenie a iné. Šimková považuje za sémantickú vlastnost́ častíc ich schopnost́ vzbudzovat neexplicitné informácie, pričom menia neutrálny prejav a „propozičný základ obohacujú d’alšími informáciami o postojoch hovoriaceho a/alebo adresáta ku komunikovanej mimojazykovej skutočnosti“ (Šimková 2001: 40).

V tomto kontexte ukazujem, ako pasáže zo súdnej komunikácie strácajú neutrálnost́ najmä na miestach, kde častice vyjadrujú vztah autora k výpovedi. Implicitne hodnotiaci aspekt v sebe mali predovšetkým persuazívne častice (asi, akože) vyjadrujúce váhanie a neurčitý postoj, vysvetl'ovacie častice (teda a tak), ako aj neurčité zámená (nejaké). Uvedené pomocné výrazové prostriedky sa vyskytovali najmä v reči sudkyne, právneho zástupcu migračného úradu a tlmočníka, kým v reči žiadatel'a o azyl a jeho právnej zástupkyne takmer absentovali. Tlmočník používal častice a zámená počas tlmočenia najmä vo chvílach neistoty, čím sa stávali súčastou tlmočeného prejavu žiadatel'a o azyl. Pre úsporu času aj zachovanie podstaty výpovedí ich sudkyňa nediktovala zapisovatelke, preto nie sú súčastou zápisnice, len audionahrávky, dostupnej účastníkom konania na vyžiadanie. Žiadatel' o azyl sa o použití častíc pridaných k jeho výpovedi nemal ako dozvediet', pričom tvrdím, že vplývali na atmosféru pojednávania a prezentácie o jeho osobe.

V tejto súvislosti je podstatné nezabudnút na limity analýzy. Pierre Bourdieu (1991) upozorňuje, že akonáhle chápeme jazyk ako autonómny subjekt, sme odsúdení hl'adat' v slovách ich vlastnú silu, teda to, čo tam nájst' nemožno. Zdroj moci niekedy zdanlivo vychádza z hovoriaceho, no v skutočnosti sídli v inštitucionálnych podmienkach produkcie a recepcie jeho prejavu. Nestačí totiž, aby bol komunikát porozumený (niekedy ani to nemusí byt') rozhodujúce je, aby bol rozpoznaný ako taký - legitímnou situáciou, legitímnymi poslucháčmi a legitímnou formou (Bourdieu 1991: 111-116). Sudkyňa tým, ako viedla pojednávanie, ako každý výrok autorizovala zápisom, stelesňovala inštitucionálne podmienky produkcie a recepcie prejavu každého 
z účastníkov. Sudcovia tak nepraktizujú len svoju profesiu, ale sú zároveň nositel'mi politiky a moci (Berti et al. 2016; Eades 2008; Eades 2010; Philips 1998; Láštic - Spáč 2017; Tužinská 2015a; 2017).

\section{Opis súdneho pojednávania}

Širšiemu spoločenskému, politickému a historickému kontextu azylových súdnych pojednávaní na Slovensku sa venujem na inom mieste (Tužinská 2015b a nasl.). Prezentované pojednávanie k žalobe voči rozhodnutiu migračného úradu o zamietnutí udelenia azylu pochádza z roku 2017. Na Krajskom súde v Bratislave boli prítomní sudkyňa (S), žiadatel' o azyl (A), právna zástupkyňa (P), tlmočník (T) a zástupca migračného úradu (M), zapisovatelka (Z) a ja ako verejnost'. Pojednávanie trvalo nezvyčajne dlho - tri a pol hodiny, v sparnom letnom počasí, v čase obeda. Tlmočenie prebiehalo z/do francúzštiny, materinského jazyka žiadatela o azyl, ktorej okrem neho a tlmočníka nik nerozumel. ${ }^{1}$

Miestom konania odvolacieho súdneho pojednávania so žiadatel'mi o azyl bol Krajský súd v Bratislave - rozsiahla budova s množstvom pojednávacích miestností, väznicou a vstupnou bezpečnostnou kontrolou. Spravidla sú v súdnych sieňach miesta na sedenie po všetkých štyroch stranách miestnosti, najširším stolom pre sudcu, s vyvýšenou podestou nad zvyškom súdnej siene, pričom po jeho pravici je miesto pre právneho zástupcu žalobcu, žalobcu (žiadatela o azyl) a tlmočníka, po jeho lavici pre zástupcu žalovaného, t. j. migračného úradu, oproti sudcu je lavica s miestom pre verejnost́. V poučení o správaní v pojednávacej miestnosti² sa uvádza, že účastníci sa môžu vyjadrovat len so súhlasom alebo na pokyn predsedu senátu, a to postojačky. Slovné prejavy majú byt' zrozumitelné, stručné a vecné.

Na pojednávaniach sú práve tieto tri - zrozumitel'nost', stručnost' a vecnost' - oblastami, ktoré každý z účastníkov nevyhnutne chápe po svojom. Pre dosiahnutie týchto ciel'ov, zvlášt ak potrebujú na premyslenie dlhší čas, aktéri používajú jazykové prostriedky lúudovo označované ako „barličky“ - častice a zámená. Počas tohto súdneho pojednávania ich používala sudkyňa, tlmočník a zástupca migračného úradu, právna zástupkyňa žiadatela o azyl zriedkavo a žiadatel' o azyl temer nikdy. Vyjadrovanie neistoty bolo dvojakého druhu: 1) pomocné častice sa v reči vyskytovali vtedy, ak bol aktér jazykovo či odborne nekompetentný, alebo ak 2) chcel zdôraznit', že pochybuje o pravdivosti výroku žiadatel'a o azyl. Mohlo by sa zdat', že je zbytočné venovat' sa časticiam, no práve cez ne sa prejavil emocionálny odtieň pojednávania, ktoré tento konkrétny prípad odlíšil od iných pozorovaní na Krajskom súde v Bratislave. V pojednávaniach s inými sudkyňami a sudcami bola prítomnost́ častíc a neurčitých 
zámen výrazne menšia. Ich výroky boli charakteristické predovšetkým dvojakou sumarizáciou - odznelo najprv zhrňujúce tlmočenie a potom zhrňujúci diktát do zápisnice, bez trvania na doslovnosti. Interpretačným posunom sumarizácií a ich vplyvu na priebeh azylových konaní sa podrobne venovalo viacero autorov (Maryns 2006; Berk-Seligson 2002). Je pochopitelné, že sudcovia aj tlmočníci zvyknú pre efektivitu času výroky zostručnit', ba aj mierne pozmenit', no ostáva otázkou, aké právne dôsledky má vol'ba miery na škále medzi úplnou doslovnostou a úplnou sumarizáciou.

Sudkyňa ešte predtým, ako spustila nahrávanie a skontrolovala identifikačné doklady prítomných, nepriamo upozornila na svoj vlastný spôsob vedenia zápisu.

S: Pôjdeme teda pomaly, poprosím účastníkov potom, aby teda, ehm, vo svojich vyjadreniach brali ohl'ad na to, že vlastne všetko sa bude tlmočit', aby pán žalobca bol teda informovaný presne o tom, ehm. Potom, ked' bude vypovedat pán žalobca, ešte pred pojednávaním chcem poprosit', aby priamo do zápisnice, všetkých požiadam, aby svoje vyjadrenia diktovali, dobre? Takže po častiach, pomaličky, aby to bolo zachytené. Dobre, takže môžeme začat'.

Pre túto prípadovú štúdiu je charakteristické, že je temer bez sumarizácií. Je tak výnimočnou ukážkou nezvyklo hyperkorektného postupu sudkyne pri tvorbe zápisnice, ako aj pri tlmočení. Zhodou okolností na tomto pojednávaní tlmočila osoba, ktorá vyžadovala úplné porozumenie komunikátu. Sudkyňa musela zmysel viet opakovane vysvetl'ovat' nielen pre tlmočníkovu miernu nedoslýchavost', ale predovšetkým pre jeho snahu komplexne porozumiet' vzniknutej situácii či právnej terminológii. Napriek tomu, že obaja, sudkyňa aj tlmočník si dali na svojich prejavoch záležat', obaja používali vo väčšej miere pomocné častice, ktoré v určitých miestach oslabovali pozíciu žiadatel'a o azyl. Hoci mali na konštrukciu jeho identity vplyv, nemal sa o nich ako dozvediet. Hoci sudkyňa prejavovala značnú únavu zo zdíhavosti vlastného postupu, trvala na doslovnosti zápisu bez vlastných sumarizácií a tlmočník trval na presnosti prekladu.

V miestnosti, kde je všetok mobiliár nemobilný a pohyb osôb zvykne byt regulovaný len pokynmi sudcu (o čom je aj upovedomenie pred vstupom do miestnosti), bola požiadavka tlmočníka neostat' za jeho stolom svojím spôsobom prekročením normy. Počas celého pojednávania sa medzi účastníkmi pohyboval a „krok sun krok“ vypíňal tak stred miestnosti, ktorý je za iných okolností vždy prázdny. Jeho pohyb sudkyňa kvôli nedoslýchavosti nemohla zakázat' a predsa dávala najavo, ako tento pohyb v rituálnom priestore síce toleruje, ale s mierne zadržaným dychom. Tlmočník pôsobil sústredene, overoval takmer každú vetu, niekedy preto, že nie celkom zretel'ne počul, inokedy preto, že mu ani počutá veta nedávala celkom zmysel. Sprvoti jeho 
pomalý preklad pôsobil ako brzda plynulosti celej komunikácie, sudkyňa pri tom miestami dávala najavo svoju netrpezlivost'. Bolo to však prvýkrát, čo som zažila preklad úplne všetkého, vrátane čísiel spisov v plnom znení. Vytvorila sa tým nerovnováha medzi časom, ktorý bol venovaný prekladu čísiel spisov a ich obsahu, teda tlmočeniu významov, ktoré mali byt́ ozrejmené. Ako sa však ukázalo neskôr, znevýhodnenie nedoslýchavého, no precízneho tlmočníka malo aj iný dôsledok: aj pri najmenšej nezrovnalosti účastníkov nepriamo donútil povedané ešte raz prerozprávat. Pri viacerých pojmoch, ktoré sú v azylových veciach bežné (doplnková ochrana napríklad), mlčky uvažoval, čo v skutočnosti znamenajú, na viaceré sa spýtal. Väčšina tvrdení tak odznela opakovane, miestami aj s dodatočným vysvetlením. Pre prekvapený výraz sudkyne otvorene uviedol, že predsa najprv musí on sám dôkladne porozumiet', čo má preložit'. V kontraste s ním tlmočníci na iných pojednávaniach pôsobili, že bud' všetkému rozumeli, alebo nie, a čast' komunikátu v mene efektivity preskočili. V tomto prípade však tlmočník opakovane overil každý význam, a to najmä v prípade, ak odznela zložitá právna formulácia. Nechal si ju najprv sudkyňou „pretlmočit“, vysvetlit', potom v slovenčine prerozprával, aby si overil, či správne porozumel a až potom ju pretlmočil nielen z cudzieho jazyka, ale aj z registra práva.

Nasledujúcej pasáži predchádzalo zdíhavé oboznamovanie účastníkov s obsahom spisu - sudkyňa 22 minút menovala názvy a hláskovala čísla spisov. V sále nastalo krátke uvol'nenie po jeho skončení o to viac, že bolo neúmerne predížené trvaním sudkyne na hyperkorektnom pretlmočení každého čísla a písmena, vrátane často sa opakujúceho písmena ž, ktoré vo francúzštine nemá ekvivalent. Po tomto úvodnom úseku, ktorý pre žiadatela o azyl prakticky neniesol význam, nasledoval priestor pre neho, ako pre žalobcu.

\section{S: Dobre. Ja by som teraz poprosila pána žalobcu, aby sa teda,} ehm, vyjadril k skutočnostiam, ktoré by chcel uviest' na tomto súdnom pojednávaní, predovšetkým, aby teda povedal o svojej totožnosti, a teda okolnosti, ktoré by mal súd vziat' do úvahy.

T: Totožnosti a potom?

S: Totožnosti a všetky tie skutočnosti, ktoré by mal súd vziat' do úvahy, z jeho uhla pohl'adu.

Žiadatel' o azyl sa postavil, začal vyjadrenie, stihol však len oslovit' sudkyňu. Na to sa postavila právna zástupkyňa a povedala sudkyni: „Má to v kópii.“

S: Pán žalobca má pripravené nejaké?

Neurčité zámeno „nejaké“ sudkyňa použila bez uvedenia predmetu mysliac tým jeho stanovisko. Na kladnú reakciu právnej zástupkyne sudkyňa vyjadrila prekvapenie, že žalobca má vyjadrenie pripravené aj v písomnej podobe. Je možné, že mala predošlú skúsenost z iných pojednávaní, ked' sa žiadatel' 
o azyl vzdal možnosti vyjadrit' sa s tým, že prenechával svoje miesto ústnym a písomným prejavom právneho zástupcu. Žiadatel' o azyl v tomto prípade využil svoje právo na vyjadrenie, pričom ho sudkyňa často prerušovala kvôli presnosti zápisu. Sudkyňa prejavovala miernu neochotu opakovaným používaním častice „teda“, následne overila, ako bude prebiehat preklad a navrhla preklad vety po vete. Žiadatel' verbálne rámcoval zmenu z „nejakého“ na „konkrétne“ napriek tomu, že mu sudkyňa neverbálne dala najavo, že ho až tak nechce počut', pretože podl'a nej nepovedal nič iné, než to, čo už je uvedené v spise.

V nasledujúcej ukážke sudkyňa v súvislosti s tvorbou zápisnice použila sloveso „protokolovat““, ktoré je síce bežné, no nie v takejto frekvencii a dôraze. Na tomto pojednávaní ním sudkyňa celkovo 11-krát zdôraznila potrebu presného zápisu.

P: Áno, bolo by to lepšie, ako sledovat', s tým, ako to prekladá, plus ešte niečo doplní, a má tú základnú verziu aj pri sebe.

S: A môžete to doložit'?

P: Ono to nie je úplne, on tam - si ešte dal dodatočné

poznámky, ale môžem to doložit'.

S: No nie, že môžete doložit', mali ste to predložit teraz na pojednávaní, lebo $v$ takom prípade budeme protokolovat to, čo teda, ehm P: To, čo bude tlmočit', protokolujte, to len pre zjednodušenie jeho tlmočenia.

S: Dobre, áno.

T: (voči sudkyni) To je jeho pozícia, to je po (v jeho rodnej reči), ked' chcete, tak ja to môžem prečitat po slovensky.

S: Áno, ja vás poprosím, takže môžem?

T: To je jeho písomné stanovisko, o ktoré ste ho požiadali, tu má spísané.

S: Dobre, takže dobre, budeme to doslova, ja, poprosím vás, pán tlmočník, pomaly, lebo pani asistentka bude priamo zapisovat do zápisnice. Takže môžeme dat' - predstúpil navrhovatel', ktorý uvádza svoje stanovisko.

T: (voči právnej zástupkyni) Môžem to preložit?

P: Môžete to prekladat'.

T: Takže vážená ctihodnost', pani sudkyňa, d'akujem.

S: (voči zapisovatelke) Predstúpil žalobca, ktorý predkladá svoje stanovisko...

Pojednávanie pokračovalo vymedzením spôsobu prekladu, v ktorom sudkyňa zdôrazňuje potrebu doslovnosti v zápise (priamo, pomaly). Tlmočník chcel pôvodne prekladat z časových dôvodov priamo z vytlačeného podkladu, ktorý si pripravil žiadatel'. Právna zástupkyňa s tým nesúhlasila, pretože chcela, aby odznel žiadatel'ov hlas, a tiež, aby mal žiadatel' možnost' prispôsobit' svoj prejav danej chvíli. 
P: Nechajte ho, nech to aj povie sám a vám sa bude aj lepšie

prekladat', on to môže hovorit'.

T: Ale to je lepšie, ked' to vidím, lebo to sú-

$\mathrm{P}$ : Ja viem, ja viem, ale on to môže čítat'.

T: Ale to meno, to ja neviem preložit.

$\mathrm{P}$ : Ale on tam má ešte svoje poznámky, takže, aby to šlo spolu s tým.

T: Čo teraz navrhujete, lebo... aby to on čítal a ja som to prekladal?

P: Áno.

$\mathrm{T}$ : Ale ja to chcem aj vidiet.

$\mathrm{P}:$ Áno, môžete to vidiet'.

Žiadatel' o azyl pokračoval a tlmočník prekladal.

Nasleduje pasáž, kde tlmočník poukázal na problém s výslovnostou mien, čo sa opakovalo počas celého pojednávania. Skomoleniny sa vyskytli aj v zápisnici, kde má jedno meno viacero variant, ktoré nepôsobili ako preklepy. Do zápisnice sa tak dostali mená/názvy, ktoré neodzneli (napríklad miesto ABCD, Acebydu, alebo Abucydi či Adicubo, miesto Gege bolo Bege). Pri každom hláskovaní sudkyňa prejavovala netrpezlivost'. Komolenie vlastného mena sa tiež radí medzi jeden z jazykových prostriedkov, ktorý môže pozíciu účastníka konania oslabovat'. Tlmočník menej zrozumitel'ne vyslovil meno žiadatel'a o azyl, ktoré bolo v zápisnici uvedené inak než v ozname o súdnom pojednávaní pri dverách miestnosti. Žalobca čítal svoj prejav plynulo, tlmočník ho prekladal prerušovane, s výrazne zmeneným rytmom.

T: Takže moje meno je XXX, som štátny príslušník ypsilonový.

S: To meno poprosíme pomalšie, lebo to je -

(sudkyňa ostala ticho, pričom skrivila pery).

Tlmočník zopakoval meno aj miesto pôvodu.

T: Som štátnej príslušnosti ypsilonovej z provincie Zetzet

a z obce Óp, Óp, Ópéqé.

T: Ehm, pani ctihodnost', vážená sudkyña, som tu preto, aby som vás požiadal, teda tribunál, ktorému predsedáte, revíziu, zmenu rozhodnutia, ktoré uskutočnil imigračný úrad, ehm, v tom zmysle, aby som, aby bola poskytnutá permanentná ochrana (pojem permanentná zhltol, akoby si nebol istý slovenským ekvivalentom).

S: (tlmočníkovi) Pomalšie (zopakoval vetu zapisovatelke).

T: Teda tá trvalá ochrana - (tlmočník v rozpakoch mlčal, nakolko sa javilo, že nepoznal významový rozdiel medzi doplnkovou ochranou a inštitútom azylu, ktorú v pojednávaní pracovne nazýval trvalá ochrana).

S: Tú vetu poprosím prečítat' ešte raz.

T: Čiže žiadam o zmenu rozhodnutia, ktorú urobil imigračný úrad, $v$ tom zmysle, že požadujem trvalú ochranu. 
Žiadatel' o azyl d'alej hovoril plynulo, prednášal z písomnej prípravy, miestami sa pozrel na sudkyňu, ale nestretli sa im oči, pretože sudkyňa mala pohl'ad zanorený v spise a hrýzla si pritom peru. Ak tlmočník povedal naraz viac viet, z pohl'adu zapisovatelky prekladal prirýchlo. Sudkyňa prejavila nespokojnost', akoby chcela mat' v spise celý prejav založený, bez prekladania aj následného zapisovania. Svoju netrpezlivost' dávala najavo vzdychaním, zdvíhaním obočia a poklepkávaním pera o stôl.

T: Ehm, vaša ctihodnost', tak ako som už vysvetlil

bezpečnostnú situáciu v Ypsilone, aj moju osobnú situáciu, vysvetlenie som poskytol migračnému úradu.

Z: Pomalšie, zapisujem, bezpečnostnú situáciu v Ypsilone...

T: Tak, ako som už vysvetlenie som poskytol migračnému úradu. Žiadatel' o azyl pokračoval.

T: Ehm, teda dovolte mi, aby som vysvetlil svoje dôvody, ehm, svojej žiadosti, teda o zmenu toho stanoviska..., aby som vysvetlil dôvody, ktoré ma priviedli k žiadosti o azyl pred vaším tribunálom.

Žiadatel' o azyl pokračoval.

T: Moja krajina sa nachádza v hlbokej politickej

kríze medzi dvoma etnikami.

S: Pomalšie, prosím.

T: Etnikum Efef - moja krajina sa nachádza $v$ hlbokej politickej kríze medzi dvoma etnikami, a to Gege, ktorí tvoria $86 \%$ populácie a Efef, ktorej som ja súčast' populácie, ktorých je $13 \%$ populácie.

S: (voči zapisovatelke) Efef.

T: Gege, a on je Efef.

T: Vaša ctihodnost', pani sudkyňa, v tejto krajine, myslí Ypsilon, byt Efef, národnosti Efef, je synonymom hlavy, ktorá má byt' odrezanáS: $V$ tejto krajine národnosti Efef?

T: Byt' Efef, národnosti Efef, je synonymom hlavy, ktorá má byt' odrezaná.

S: Ako??

Z: Hlavy, ktorá má byt' odrezaná?

T: Áno, to znamená, Efef je synonymom hlavy, ktorá má byt' odrezaná, takto je to tam (v prejave žiadatel'a o azyl) napísané.

$\mathrm{S}$ : Ja som sa len pýtala.

T: Áno, že ked' má niekto národnost' Efef, tak tá väčšina chce ich odrezanie hlavy. Efef je takisto synonymom nepriatela, ktorý musí byt eliminovaný.

A: hovorí.

T: Mladí ludia sú v našej krajine upalovaní kvôli politickej príslušnosti, (žiadatel' o azyl pokračoval)

T: a takisto im odrezávajú končatiny.

Ostalo ticho, sudkyňa sa spýtavo pozrela. 
T: Príslušníkom Efef, im odrezávajú končatiny. Tisíce z nich sa nachádzajú vo väzniciach, kde neexistuje žiadne právo vyjadrit'sa, a dá sa povedat, že celá naša krajina sa stala väznicou pod holým nebom.

Z: Že celá naša krajina sa stala väznicou?

S: Pod holým nebom.

T: Z tohto dôvodu Vás, pani ctihodnost', pani sudkyňa, prosím o poskytnutie trvalej ochrany -

Tlmočník nerozumie nasledujúcemu výrazu a hláskuje si napísané so žiadatel'om.

T: Coeur net. Tuto sa piše, že preto žiada o poskytnutie trvalej ochrany, aby mal čisté srdce za všetky tieto barbarstvá, ktoré sú za mnou, ktoré prežil.

Nastala silná chvíla ticha, ovel'a dlhšia, než býva medzi vetami. Žiadatel' o azyl pokračoval v opise budúcnosti krajiny aj svojho prežitia. Tlmočník v preklade d'alej zamieňal prvú a tretiu osobu, priamu a nepriamu reč, čo miestami pôsobilo mätúco na sudkyňu aj na zapisovatelku.

T: To je to, čo, pani sudkyňa, to sú dôvody, ktoré ma ako tlačia, alebo ktoré nútia, pred vašou inštitúciou požiadat́ o trvalú ochranu, pretože preňho návrat do Ypsilonu je synonymom istej smrti. Možno, že sa vám to zdá smiešne, ale určite by som bol radšej u vás vo väznici, ako sa vrátit' do Ypsilonu. Tak to je jeho ako stanovisko, toto, čo povedal. Z: Ešte napíšem, že to je jeho stanovisko?

S: Nie, to je ako, alebo - (voči T ) - mám tam dat', ako že to je stanovisko žalobcu, alebo to je ako koniec, hej, čo tam? Chce ešte niečo doplnit', alebo? Tlmočník si otázku sudkyne overil so žiadatel'om.

T: Áno, to je koniec jeho stanoviska na základe vašej výzvy, aby povedal svoju -

S: Áno, rozumiem, takže to nemusíme protokolovat. Dobre.

Pojednávanie pokračovalo vyjasňovaním vztahov jednotlivých aktérov. Tlmočník opakovane viedol samostatný dialóg so žiadatelom, aby pochopil súvislosti, napokon sumarizoval s pomocnými časticami, slovesami a zámenami: takže, akože, dá sa povedat', na nejakom, vlastne, asi, ten a tak. Sudkyňa opakovane dvíhala oči stĺpkom a často sa usmievala. V nasledujúcej pasáži žiadatel' odpovedal na doplňujúce otázky právnej zástupkyne, tlmočník mal problém so správnym vyslovením mien.

T: Takže to, že som blízky akože s tým advokátom pánom Á-bý-cé-dé, ktorý je považovaný za verejného nepriatela štátu, ale teda aj to, že patrím do etnika Efef.

$\mathrm{S}$ : Pomalšie. 
(...)

T: Takže bol vedúcim jeho diplomovej práce sa dá povedat' a zároveň pracoval na nejakom projekte. Žiadatel' o azyl hovorí d'alej.

T: Aha, na nejakom dotazníku spolupracovali.

S: Ešte nejaká otázka? (netrpezlivo)

(...)

S: Ešte niečo? (netrpezlivo)

(...)

T: No takže, ako už spomínal, tento profesor Á-bý-cé-dé je v očiach štátnych orgánov nepriatel štátu, a ja som jeho žiak, ehm, tak ma aj považujú, akože som vlastne jeho stúpenec.

Z: Žiak... stúpenec, áno?

T: Stúpenec, no, akože tiež ho asi považujú za nepriatela štátu.

(...)

T: Je to všetko preto, pretože vyznávam také isté hodnoty ako ten profesor Á-bý-cé-dé.

S: (voči zapisovatelke) Že vyznáva rovnaké hodnoty.

T: Takže ctí si ústavu a tak.

P: Viedli vás k tomuto presvedčeniu, že štátne orgány...

Overila som, že žiadatel' o azyl vo svojej materinskej reči nepoužíval výrazy „tak, akože, vlastne, dá sa povedat“", preto možno tvrdit', že ich tlmočník dodával, predpokladám, že nevedome. Ostávali mimo zápisnice podobne ako slová sudkyne „dobre, dobre, pomalšie, ešte nejaká otázka“, ktoré zapisovatelka tiež nemala prečo zapisovat'. Všetky tieto jazykové formy spolutvorili atmosféru pojednávania, pričom tvrdím, že prispievali k postupnému zmenšovaniu argumentačnej sily prejavu žiadatel'a o azyl. Vsuvky sudkyne „ešte“, „otázka“, „dobre“ boli akoby vo forme otázky, rytmicky však nemali na konci otáznik. Paradoxne, jej neverbálne prejavy týmto slovám dávali opačný význam, ako keby jej skutočným cielom bolo nemat' už žiadnu otázku. V tomto kontexte sa nemožno uspokojit so samotným nominálnym výrazom, pretože len poznanie kontextu umožní postrehnút, ako sudkyňa implicitne ukončuje prejav žiadatel'a o azyl. Hoci sudkyňa chcela komunikáciu urýchlit', spomal'ovala ju hyperkorektným trvaním na doslovnosti v zápisnici, ktorá je plná gramatických, štylistických aj obsahových chýb.

V zápisnici nevidiet', ako postupne rôzne odmlky, pohl'ady a nepoložené otázky vygradovali do výroku sudkyne: „žaloba sa zamieta“. Tieto priebežné prejavy spochybňovania, ako aj mimoriadne krátku prestávku pred záverečným výrokom právna zástupkyňa považovala za signál, že zamietavý rozsudok mala sudkyňa pripravený ešte pred pojednávaním.

Právna zástupkyňa pokračovala doplňujúcimi otázkami. Tlmočník prekladal - žiadatel' síce povedal: „zadržali by ma“, ale tlmočník pretlmočil: „bol by 
zadržaný“. Zmena z aktívu na pasívum je tiež jedna z častých foriem oslabenia výpovednej sily (Maryns 2006). Nad'alej používal neurčité častice (vlastne, asi), menil prvú osobu na tretiu, činný na trpný rod, dopĺňal „myslí si, že“. Sudkyňa prepočula silnejší výraz „likvidovaní“.

P: Čoho sa obávate v prípade návratu do krajiny pôvodu?

T: Myslí si, že by bol okamžite teda za-zadržaný a by bol vlastne asi zlikvidovaný. Hned', ako zostúpil z lietadla.

S: Bol zlikvidovaný - po príchode lietadla, teda po vystúpení z lietadla?

T: No, si myslí, že by bol zadržaný a by bol zlikvidovaný.

S: Áno, dobre.

T: L'udia, ktorí robia v štátnej správe v Ypsilone a sú Efefovia, tak ich postupne všetkých prepúštajú, alebo teda likvidujú, teda ich zabijajú.

S: (voči zapisovatelke) Postupne prepúštaní.

$\mathrm{P}$ : Alebo likvidovaní.

$\mathrm{S}:$ No, tak to ste povedali vy, ale nie pán-

$\mathrm{H}$ : Povedal to, povedal.

S: Povedal? Hej? Dobre.

T: Povedal.

V tejto chvíli od začiatku pojednávania prešla hodina a pol, v čase obeda, je sparno v miestnosti. Po prejave žiadatela o azyl mala dostat́ slovo právna zástupkyňa, opät konzekutívnym tlmočením. Sudkyňa právnej zástupkyni signalizovala žiadost', aby bola čo najstručnejšia.

S: No, všetko? Takže ešte vaše stanovisko (voči právnej zástupkyni).

Lebo máme tu toho pána žalobcu. Tým, že sa znova musí

prekladat', prosím vás, zvážte, lebo žaloba je súdu známa, takže

- niečo, čo by ste chceli ešte prípadne nad rámec tohto...

P: Vážený súd, žalobných bodov-

(sudkyňa skočila do reči so zvýšenou intonáciou, aby ju zastavila, otočila sa voči zapisovatelke).

S: Právna zástupkyña žalobcu uvádza, a prosím nadiktovat', budeme to musiet zase prekladat', takže dve vety-preložíte, lebo máme tuná - (odmlčala sa) - pána žalobcu.

P: V plnom rozsahu sa pridržiavame žalobných bodov právnej

argumentácie žalobného návrhu tak, ako je uvedené v správnej

žalobe. Sme presvedčení-

S: (sudkyňa ju pohl'adom zastavila) No ja som chcela

dat' slovo tlmočníkovi.

P: Dobre.

$\mathrm{T}$ : Ešte keby ste zopakovali.

P: My sa pridržiavame správnej žaloby. 
S: (voči tlmočníkovi) A právnej argumentácie tak, ako bolo uvedené $v$ správnej žalobe. $V$ plnom rozsahu sa pridržiavame, sa pridržiavame žalobných bodov právnej argumentácie žalobného návrhu, tak ako je uvedené v správnej žalobe. Dobre.

Právna zástupkyňa svoj prejav čítala v mierne skrátenej verzii. Po každých dvoch vetách čakala, aby tlmočník pretlmočil a zapisovatelka zapísala. Na iných pojednávaniach sudcovia na tomto postupe netrvali, ale vypýtali si prejav právnych zástupcov, ktorý krátkou cestou založili do spisu ako prílohu k zápisnici. Tiež navrhli, aby prejav tlmočník netlmočil, pričom si na to vypýtali súhlas žiadatela o azyl. Aby predišli chybám zapisovatelky, tak právni zástupcovia mohli prejav poslat' aj elektronickou poštou, pričom na mieste ho vol'ne predniesli v podobe sumáru najdôležitejších bodov. Ak by žiadatel' o azyl nebol na súde prítomný, pojednávanie by mohlo byt skončené do pol hodiny.

V časti prejavu, ktorý na tomto mieste neuvádzam v plnosti pre jeho rozsah, si tlmočník nebol istý prekladom právnej terminológie a vyjasňoval si význam termínov priebežne s právničkou. Napríklad prelínanie politických dôvodov s etnickými dôvodmi, pojmy skutočný a pripisovaný. Tiež ju prosil, aby nehovorila dlhé vety, „pretože sa mi vel'mi zle prekladajú, musia sa delit a potom je problém s ich skloňovaním“. Právna zástupkyňa hovorila o krutom mučení a neludskom zaobchádzaní, zapisovatelke diktovala každú vetu v priemere dvakrát. Niekedy vetu povedala aj tretíkrát, pre tlmočníka, ak povedal, že mu zmysel vety unikol - napríklad, ak v nich boli výrazy „bola naplnená skutková podstata“, „, všeobecná dôveryhodnost žalobcu“, „opodstatnenost obáv z prenasledovania“, alebo „princíp pochybnosti v prospech žiadatel'a“. Sudkyňa dávala opakovane najavo, že aj tento prejav považuje za zbytočný, prevracala oči, nahlas vzdychala. Povzdychol si aj predstavitel' migračného úradu, ktorý ešte len mal dostat' slovo. K opisom brutálneho mučenia, ktoré by žiadatel'ovi o azyl hrozilo v prípade návratu do domoviny, tlmočník prejavil velké zdesenie a dôkladne ich tlmočil žiadatel'ovi o azyl, ktorý prikyvoval na svoj vlastný prerozprávaný príbeh. Sudkyňa zatial' listovala v spise, právnička sa dívala do očí zapisovatelke. Ani tento prednes v trvaní 40 minút nebol plynulý, nielen kvôli konzekutívnemu tlmočeniu, ale najmä pre spomalené diktovanie zapisovatelke.

Prešli dve a štvrt' hodiny od začiatku pojednávania, bola takmer jedna hodina poobede. Účastníci si zatial' vypočuli obsah spisu v podaní sudkyne a dva prejavy - žiadatel'a o azyl aj jeho právnej zástupkyne. Detailne v nich vysvetl'ovali opodstatnenost́ obáv o život v prípade návratu žiadatela o azyl do krajiny jeho pôvodu. Nasledoval prejav zástupcu migračného úradu, ktorý zdôrazňoval, že obavy žiadatel'a sú nepodložené, nakolko podla neho v minulosti nebol prenasledovaný. Potom, čo vyše dve hodiny tlmočník opisoval detaily o „krutom a neludskom zaobchádzaní“, neskrývane prejavil prekvapenie. 
Zástupca migračného úradu uviedol odkaz na nemenovaného kolegu (až 9x), akoby potreboval legitimizovat ním uvedené údaje. Utvrdenie hodnovernosti informácie uzatvoril (na pojednávaniach relatívne častou) vetou: „No, to je v spise uvedené.“

T: Ešte raz, tomu nerozumiem, že vlastne nemal nijaké problémy? A potom?

M: No nemal tam žiadne, teda také problémy, okrem toho jedného zadržania.

T: Okrem toho jedného zadržaniaM: Áno, áno.

$\mathrm{T}:$ A potom?

M: Bez ohl'adu na to jedno zadržanie, lebo on (ležérny tón) vlastne mal na starost' nejaké tie kontakty s nejakými inštitúciami, vybavoval na rôznych úradoch rôzne veci-

S: No moment, to ešte nie je v zápisnici, takže $\mathrm{M}:$ To bolo $v$ tej vete myslené.

S: Tak myslené, dobre.

T: No preto som povedal, že nemal problémy okrem toho jednodňového zadržania.

M: Že sa mu v tej dlhodobej, že sa vlastne mu darilo všetko vybavovat' aj presúvat. To povedal jeho kolega, čo s ním pracoval.

S: (promptne) Čo potvrdil aj kolega,

M: (opakuje dôrazne tlmočníkovi) čo potvrdil

aj kolega, ktorý s ním pracoval,

S: čo potvrdil aj kolega, ktorý s ním pracoval (opät voči zapisovatelke), ešte poprosím, čo potvrdil aj kolega, ktorý s ním pracoval.

T: Prosím?

S: (hlasnejšie) Čo potvrdil aj kolega, ktorý s ním pracoval.

T: Tieto skutočnosti?

S: Tieto skutočnosti, čo ste teraz preložili.

$\mathrm{T}$ : Čo sme povedali -

Tlmočník tlmočil, on aj žiadatel' ostali prekvapení, tlmočník zdôraznil ,jeho“.

T: Jeho kolega? Alebo?

M: Jeho kolega.

Tlmočník tlmočí.

T: Tak mu ešte raz hovorím, že podla vás, nemal žiadne problémy okrem toho jednodňového zadržania, a toto bolo dokázané, teda potvrdené.

M: Na úrady chodil, pohyboval sa, čo bolo treba.

T: To potvrdil aj jeho kolega.

M: To potvrdil aj jeho kolega, áno.

T: Akým kolegom? 
M: Kolega z univerzity, alebo s kým spolupracoval v Ypsilone.

No to je $v$ spise uvedené (a oprel zrak na spis).

Na celom pojednávaní sudkyňa venovala mimoriadnu pozornost zapísaniu každého detailu, s výnimkou objasňovania výrazu „čisté srdce“, po ktorom nastalo v pojednávacej miestnosti dlhšie ticho. Pojem „pomalšie/pomaly“ použila celkom 21-krát.

Blížil sa záver pojednávania. Tlmočník zamlčiaval podmet. Sudkyňa skočila tlmočníkovi do reči, paralelne diktovala zapisovatelke. Žiadatel' o azyl v závere rozumel, ako tlmočník povedal v slovenčine nesprávny údaj a stihol ho opravit'.

S: Dobre. Chcete ešte niečo dodat'?

P: Žalobca?

Žiadatel' o azyl oslovuje sudkyňu a d'akuje jej.

T: No tak chce sa pod'akovat' ako, že ste pani sudkyña, mali trpezlivost' ho vypočut.

S: Žalobca v závere uvádza, že d'akuje súdu.

T: Pretože to nie je samozrejmé, ako v Ypsilone.

S: Že d'akuje súdu, že ho mal trpezlivost' vypočut', pretože to nie je samozrejmé.

S: (voči T) Pretože to nie je samozrejmé?

T: No tak, aj že ste sa vlastne korektne chovali, že to nie je automatické.

$\mathrm{S}$ : A tiež za korektné chovanie.

Žiadatel' o azyl pokračoval.

T: Pretože spravodlivost'v Ypsilone ako reálne nefunguje.

S: Pretože spravodlivost' reálne nefunguje. V Ypsilone.

T: No tak hovorí, že sa tuná mal právo sa vyjadrit', a tak d'alej. Čo by teda zrejme nebolo poskytnuté $v$ tej jeho krajine.

S: A tiež za to, že mal vo veci sa plnú možnost' vyjadrit'.

Žiadatel' o azyl pokračoval.

T: Že bol by rád, teda, že vd'aka tej ochrane dodatočnej, ktorá mu bola poskytnutá na dobu jedného roku, že by bol rád, keby mu bola predlžená na 5 rokov.

A: No, no.

Tlmočník si vyjasnil, prečo žiadatel' nesúhlasil s údajom 5 rokov.

T: A nie, trvalú chce. Nie 5 rokov, ale trvalú.

S: A keby bola trualá.

Sudkyňa žalobu zamietla. Po skončení pojednávania tlmočník na chodbe pokrútil hlavou a skonštatoval: „Mala by do Ypsilonu vycestovat'.“ 


\section{Záver}

Predložená štúdia je sondou do inštitucionálneho prostredia súdu a jeho komunikačných a jazykových noriem, ktoré v tomto prostredí vytvára sudkyňa ako zastupitelka najvyššej autority štátu a tlmočník ako jazyková autorita. Žiadatel' o azyl vstupuje už do vytvorenej komunikačnej hegemónie (Briggs 1984).

V tomto zmysle je jazyk pre inštitúcie konštituujúci, teda je prostriedkom, cez ktorý inštitúcia formuje koherentnú sociálnu realitu (Vráblová 2018).

Jazykových aj mimojazykových prostriedkov, ktoré majú vplyv na argumentačnú silu prejavu žiadatel'a o azyl, je mnoho. Spoločenský, politický, ale najmä historický kontext azylových súdnych pojednávaní je nesporne zásadný. Zároveň však práve lingvistické mechanizmy tento široký kontext stelesňujú a legitimizujú. $V$ tomto zmysle bolo cielom príspevku sprostredkovat' vplyv jazykových prostriedkov, ktoré zvyčajne ostávajú mimo zápisnice. O pridaní neurčitých zámen a častíc k jeho prejavu sa žiadatel' o azyl nemal ako dozvediet, pričom tvrdím, že vplývali nielen na atmosféru pojednávania, ale aj na prezentáciu žiadatela.

V predloženej štúdii som tak upozornila na presupozičný obsah vybraných slov, ktoré implikovali hodnotiace východisko. Slová akože, nejaký, asi, vlastne, teda, len, takže, myslí si, že - pridané k prejavu žiadatel'a o azyl prispievali nielen k významovému posunu komunikátu. Ich situačné používanie možno označit ako jeden zo spôsobov oslabovania dôveryhodnosti účastníka konania. Tlmočník nepostupuje podla profesionálnych štandardov a neznalostou odbornej terminológie znevýhodňuje žiadatela o azyl (viac pozri Štefková 2013; Guldanová 2013; 2014; Lipovec Čebron - Pistotnik 2018). Ostáva otázkou, do akej miery tlmočník môže štylisticky zasahovat' do prekladu tak, aby ho prispôsobil normatívu zápisnice.

Okrem toho, sudkyňa a právny zástupca žalovanej strany nerozpoznali, že tlmočník určitými výrazmi prejav žiadatel'a zneistoval, a tiež pridávali hodnotiace výrazy, čím istým spôsobom autorizovali svoje výroky. S týmto postupom sa dá empatizovat', no nie sympatizovat. Ako upozorňuje Anthony Good, profesionáli, ktorí sú vystavení vyššiemu stresu, sa môžu chciet dištancovat voči traume, ktorej sú opakovane vystavovaní cez jej popieranie, minimalizáciu závažnosti situácie, ale aj hnevom, nedostatkom empatie či cynizmom, no nedeje sa tak bez dôsledkov na súdne zhodnotenie dôveryhodnosti žiadatel'ov (Good 2007: 196; Petrovic 2018).

Všetci účastníci sa tak podiel'ali na „nerozpoznaní“, ako ho formuloval Pierre Bourdieu: „Jazyk autority nikdy nevládne bez spolupráce tých, ktorých ovláda, bez pomoci sociálnych mechanizmov schopných vyprodukovat túto spoluúčast' založenú na nerozpoznaní, základe všetkej autority“ (Bourdieu 1991: 113, prel. H. T.). V zhode s argumentáciou Eadesovej (2008) a Bourdieua (1991) som tak na etnografických detailoch zo súdneho pojednávania ukázala, 
ako sa prostredníctvom vol'by výrazových prostriedkov sociálny poriadok reprodukovaný v súdnej sieni javil ako samozrejmý.

Jazykové prostriedky, ktoré pridávali pochybnost', neurčitost či domnienku, menili celkovú atmosféru pojednávania nenápadne. Opísané súdne pojednávanie považujem na jednej strane za výnimočné explicitnostou komunikačnej hegemónie, na druhej strane za bežné v tom, že z pohl'adu žiadatel'a o azyl (vo väčšine pojednávaní) ide o všetko, a zd'aleka nie „akože“ či „nejako“. Opisované napätie, ktoré vzniklo z banálnych tlmočníckych chýb, nemôže nebyt súčastou rozhodnutia súdu, hoci ho nepodmieňuje. Ukázala som, ako sa hegemonické praktiky nastol'ovania súhlasu prejavujú práve cez tolerovanie nenápadných, ale rozkladných chýb: použitie tretej osoby miesto prvej, trpného rodu miesto činného, zamlčanie podmetu či autorstva, podčiarkovanie subjektivity výpovede žiadatela o azyl jazykovými aj mimojazykovými formami. Voči ich použitiu sa nik neohradil. Jestvovali mimo zápisnice, rutinne.

\section{November 2018}

\section{Literatúra}

Berk-Seligson, Susan. 2002. The Bilingual Courtroom. Court Interpreters in the Judicial Process. 2nd ed. Chicago: The University of Chicago Press.

Berti, Daniela - Good, Anthony - Tarabout, Gilles (eds.). 2016. Of Doubt and Proof. Ritual and Legal Practices of Judgement. London: Routledge.

Blommaert, Jan. 2011. Pragmatics and discourse. In: Rajend Mesthrie (ed.): The Cambridge Handbook of Sociolinguistics. Cambridge, U. K.: Cambridge University Press: 122-137. Bourdieu, Pierre. 1991. Language and symbolic power. Harvard University Press.

Briggs, Charles. 1984. Learning how to ask. A sociolinguistic appraisal of the role of the interview in social science research. Cambridge: Cambridge University Press.

Conley, John M. - O’Barr, William M. 2005. Just Words: Law, Language, and Power. Chicago: The University of Chicago Press.

Eades, Diana. 2008. Courtroom talk and Neocolonial Control. Berlin: Mouton de Gruyter. Eades, Diana. 2010. Sociolinguistics and the Legal Process. MM Textbooks.

Good, Anthony. 2007. Anthropology and Expertise in the Asylum Courts. New York: Routledge-Cavendish.

Guldanová, Zuzana. 2013. Problém preložitel'nosti/nepreložitel'nosti v kontexte súdneho tImočenia/prekladu. In: Kontexty súdneho prekladu a tImočenia II.

Ed. Zuzana Guldanová. Bratislava: Univerzita Komenského Bratislava: 51-60.

Guldanová, Zuzana. 2014. Niekol'ko pohl'adov na činnost' súdneho tlmočníka/prekladatela zo súdnej praxe. In: Kontexty súdneho prekladu a tımočenia III.

Ed. Zuzana Guldanová. Bratislava: Univerzita Komenského Bratislava: 50-67.

Láštic, Erik - Spáč, Samuel (eds.). 2017. Nedotknutel'ní. Politika sudcovských kariér na Slovensku v rokoch 1993-2015. Bratislava: Univerzita Komenského v Bratislave.

Lipovec Čebron, Uršula - Pistotnik, Sara. 2018. (Im)mobile populations and health rights: accessing the healthcare system in Slovenia. In: Vindrola-Padros, Cecilia (ur.) - Johnson, Ginger A. (ur.) - Pfister, Anne E. (ur.): Healthcare in motion: immobilities in health service delivery and access. Worlds in motion, vol. 5. New York - Oxford: Berghahn Books: 53-71. Maryns, Katrijn. 2006. The Asylum Speaker: Language in the Belgian Asylum Procedure. 1st ed. Manchester: St. Jerome Publishing. 
Mistrík, Jozef. 1985. Štylistika. Bratislava: Slovenské pedagogické nakladatel'stvo.

Petrović, Duško. 2018. “Humanitarian exceptionalism. Normalization of suspension of law in camp and corridor." In: Bužinkić, Emina - Hameršak, Marijana (eds.): Formation and Disintegration of the Balkan Refugee Corridor: Camps, Routes and Borders in Croatian Context. Zagreb - München: Institute of Ethnology and Folklore Research (Zagreb), Centre for Peace Studies (Zagreb), Faculty of Political Science University of Zagreb - Centre for Ethnicity, Citizenship and Migration: 43-62.

Philips, Susan U. 1998. Ideology in the Language of Judges. How Judges Practise law, politics, and Courtroom Control. New York: Oxford University Press.

Šimková, Mária. 2001. O lexikálnom význame častíc. Slovenská reč 66: 37-51.

Štefková, Marketa. 2013. Právny text v preklade. Translatologické aspekty právnej komunikácie v kombináciách málo rozšírených jazykov. Bratislava: Iura Edition.

Tužinská, Helena. 2015a. TImočenie v štátnej správe: deskriptívne a preskriptívne prístupy. Sociální studia 2: 51-68.

Tužinská, Helena. 2015b. TImočenie, migranti, štát: rozpoznanie jazykových registrov. In: Wachtarczyková, Jana - Satinská, Lucia - Ondrejovič, Slavomír (eds.): Jazyk v politických, ideologických a interkultúrnych vztahoch. Sociolinguistica Slovaca 8. Bratislava: Veda: 243-258.

Tužinská, Helena et al. 2017. Anthropology as necessary unlearning. Examples from camps, courts, schools and businesses. Etnološka tribina 40, 47: 3-42.

Vrábl'ová, Júlia. 2018. Specifics of institutional management of the national language in Slovakia. In: National language institutions and national languages. Contributions to the EFNIL Conference 2017 in Mannheim. Budapest: Research Institute for Linguistics, Hungarian Academy of Sciences; 85-99. 